\title{
Climate Governance Entrepreneurship: Emerging findings and a new research agenda
}

\author{
Elin Lerum Boasson and Dave Huitema
}

\begin{abstract}
This is an introductory paper to a special issue on climate governance entrepreneurship, where entrepreneurship is understood as acts performed by actors seeking to "punch above their weight'. By contrast, actors who are merely doing their job are not 'entrepreneurs'. In order to understand climate policy and governance, we need to learn more about the factors that condition variance in entrepreneurial activity, strategies and success. In this introduction, we present a comprehensive review of the literature on entrepreneurs and entrepreneurship in policy in governance, with special attention to the recent upsurge in studies of climate governance entrepreneurship. We distinguish two types of entrepreneurship: (1) acts aimed at enhancing governance influence by altering the distribution of authority and information; and (2) acts aimed at altering or diffusing norms and cognitive frameworks, worldviews or institutional logics. The contributions in this special issue offer valuable insights into how personal motivations, policy windows, international trends, cultural-institutional traditions and the distribution of structural power influence entrepreneurship. However, more work is needed - not least as regards whether actors that seek change are more active and/or more successful as entrepreneurs compared to those that defend the status quo, and whether there is more successful entrepreneurship in public or in private arenas of governance.
\end{abstract}

Keywords: Entrepreneurship, policy entrepreneur, climate governance, climate policy, framing. 


\section{Introduction}

Many have opinions about climate change, but fewer aim to accelerate, stall or shift climate policy and governance. Persistent and skilled actors who launch original ideas, create new alliances, work efficiently or otherwise seek to 'punch above their weight' (see Green, this issue), can be said to perform climate policy and governance entrepreneurship. The absence of a strong and binding climate agreement had made such entrepreneurial action increasingly important. A better grasp of entrepreneurship is crucial to understanding climate policy and governance - private or public, international or local. This introduction to a special issue of $E P C$ presents recent findings from the general policy and governance literatures on entrepreneurship, and studies of climate governance entrepreneurship more specifically. We also launch a new research agenda for studies of climate governance entrepreneurship and discuss how the articles in this special issue contribute to this agenda.

Greater scholarly attention to entrepreneurship is a natural response to the state of climate policy and governance, especially since as the certainty of the scientific conclusions presented by the Intergovernmental Panel on Climate Change (IPCC) has increased over the past two decades. It has become clear that society needs to act swiftly, adopting and implementing radical and demanding measures to deal with the climate crisis - but the wider governance system has become less, not more, certain. Global climate governance has shifted from the top-down, legally binding state-centric international regime model of the 1990s, to a more open, bottom-up pattern that relies on a broader range of governance measures, from public as well as private actors, from international, national, regional and local actors, drawing on inputs from expert groups as well as on social movements and grassroots initiatives. This shift has not gone unnoticed in the academic community: there has been an upsurge in new concepts to capture this empirical shift: 'institutional fragmentation' (Zelli and van Asselt, 2015), 'orchestration' (Abbott, 2015) and 'polycentric governance' (Jordan et al., 2015), to name but three.

The small but growing body of literature on entrepreneurship in climate governance has focused on various levels and loci of policy development and governance: the local and regional levels (Brouwer, 2013; Lovell, 2009; Wejs 2014), the national (Boasson, 2015; Huitema and Meijerink, 2009), the European Union (EU) level (Boasson and Wettestad, 2014; Buhr, 2012) and the transnational level (Green 2014; Pattberg 2012). These and other works paint a nuanced and sophisticated picture of entrepreneurship, avoiding the trap of focusing on the individual actions of heroic figures. Rather, they examine more specific analytical issues: entrepreneurial 
strategies, the key role of collaboration between those seeking change, and how political, structural and cultural-institutional contexts influences entrepreneurial activities. This special issue of EPC seeks to break new ground, offering new insights into how entrepreneurship can influence climate governance - and, we hope, contributing to more coherent cumulative research on how entrepreneurs and entrepreneurship may influence policy and governance.

Adapting to and mitigating climate change requires radically new ways of organizing and steering dominant industry and business activities, as well as the core functions of the state apparatus. Practices and traditions that have served industries and the public well for decades may no longer be appropriate: this may apply to how we audit corporations and assess legislative proposals, how we organize energy transmission, our dietary habits and modes of transportation, among other areas. The challenges will be daunting. Change is always difficult, particularly when it may involve potential threats to core functions in the economy. Classic political science approaches centred on rational actors and economic interests can explain much of the resistance and slow pace of change (see for instance Underdal, 2002). However, we hold that there has been more change than expected, given the generally pessimistic outlook provided by political science. The past decade has seen a steep increase in the adoption of climate policies and measures - in the public and private realms, nationally and internationally (Bulkeley et al., 2012; Dubash et al., 2013; Somanathan et al., 2014).

To grasp how these changes have come about we need a deeper understanding of entrepreneurship. Improved theories of entrepreneurship can help to explain what individual actors and small groups may do to challenge entrenched power structures, and why they sometimes succeed. We do not argue that actors who master the art of entrepreneurship will always succeed: it is important to understand how entrepreneurial strategies differ across time and space, and why some strategies manage to overcome the structural barriers to influence, but not others.

The understanding of entrepreneurship has proven elusive and hard to apply in empirical studies. Many conceptualizations have focused on the characteristics of the individuals who perform entrepreneurship, and not the acts they perform. However, it is challenging for scholars of policy and governance to apply definitions based on intrinsic individual characteristics of the actors under study, largely because actions are far easier to identify and study empirically than are inner human qualities. Hence, we will understand entrepreneurship as referring acts performed by actors seeking to 'punch above their weight' (see Green, this issue). By contrast, actors who are merely doing their job are not entrepreneurs. 
To distinguish between those actors who perform entrepreneurship and those who do not requires a more operationalized definition. This is crucial for the development of a more cumulative research practice, where similarities and differences in entrepreneurship can be compared across countries and sectors, and the variation assessed. In the following, we explore two categories of entrepreneurship: (1) acts aimed at enhancing governance influence by altering the prevailing distribution of authority and information; and (2) acts aimed at altering or diffusing norms and cognitive frameworks, worldviews or institutional logics.

The special issue contains six articles that assess empirical cases of entrepreneurship. Michael Mintrom and Johanna Luetjens discuss and compare how entrepreneurship contributed to the emergence of the C40 Cities Climate Leadership Group and the Carbon Disclosure Project. Katja Biedenkopf explores the motivations of US governors in relation to regional emissions trading systems (ETSs) and their influence on these processes. Moshe Maor draws on insights from the sociology of valuation, and distinguishes four types of entrepreneurship: norm, reputation, meaning, and standard and performance metrics entrepreneurship. Sebastian Jodoin zooms in on the relation between international politics and national policy change. He specifies four strategies that domestic policy entrepreneurs draw on to enhance their influence on national policy. He applies this framework to a study of deforestation and forest degradation, the conservation and sustainable management of forests, and the enhancement of forest carbon stocks in developing countries (the REDD+ initiative). Phillip Pattberg studies the global institutionalization of carbon disclosure, noting how entrepreneurs have influenced this process in four stages of its development. Inken Reimer and Barbara Saerbeck explore the entrepreneurship involved in the agenda setting and institutional anchoring of REDD+ in Norway - the most important donor country to this international mechanism. In the seventh article, Jessica Green discusses and assess these contributions, offering a comparative approach to the study of climate governance entrepreneurship.

Moving on to discuss how entrepreneurship and entrepreneurial strategies are understood in the literature, we then develop our own operational conceptualization of entrepreneurship. Next, we discuss how the literature deals with important topics, noting the need for more comparative research on variance in entrepreneurial strategies as well as in entrepreneurial success. We present a future research agenda focused on actor-specific as well as context-specific factors, listing a range of central research questions for future governance entrepreneurship studies. Further, we systematically discuss how the six empirical contributions to this special issue deals with these questions. This special issue does not aim to settle or 
resolve the challenges facing climate policy and governance entrepreneurship studies - our intention is to foster lively discussion. Bolder, systematic and explicitly comparative research is needed to identify better answers to the questions discussed in this introduction.

\section{Defining Entrepreneurship and Entrepreneurial Strategies}

Entrepreneurship is hardly a new topic. In political science for instance, back in 1961, Robert Dahl argued that policy entrepreneurs would be especially 'skilful or efficient in employing the political resources at their disposal' (Dahl, 1961:272, italics in the original). Nelson W. Polsby gave more weight to the creative aspect, seeing entrepreneurs as those "who specialize in identifying problems and finding solutions' (Polsby, 1984:171). However, it was John Kingdon (1984) who first offered detailed theorization and conceptualization on the role of entrepreneurship in policy development. In this seminal contribution, he held that entrepreneurs are characterized by their 'willingness to invest their resources - time, energy, reputation and sometimes money - in the hope of a future return' (Kingdon, [1984] 1995:122).

Since then, entrepreneurship has been explored and discussed by scholars from various strands of social science. In the early 1990s, entrepreneurship attracted considerable attention in public administration studies (e.g. Roberts, 1992; Schneider and Teske, 1992). More recently, there has been an increase in 'entrepreneur' and 'entrepreneurship' studies of societal, institutional and political change within various subfields of social science - such as national policy studies (e.g. Bakir, 2009; Boasson, 2015; Huitema and Meijerink, 2009; Lovell, 2009), EU policy studies (e.g. Ackrill and Kaym 2011; Ackrill, Kay and Zahariadis, 2013; Buhr, 2012; Corbett, 2005), studies of transnational regulation and governance (Green, 2014; Pattberg, 2012) and neo-institutional sociology (e.g. Buhr, 2012; Fligstein and McAdam, 2012; Hardy and Maguire, 2008). In addition, we can note the upsurge of interest in entrepreneurship in the field of science and technology studies (e.g. Hermansen 2015) and planning studies (e.g. Wejs, 2014).

Some 25 years ago, Nancy Roberts (1992:56) pointed out that it was difficult to interpret the state of entrepreneurship research because there was no consensus on what it was. This challenge remains. Contact has been limited among the various research communities involved (e.g., public policy, public administration and neo-institutional sociology), so definitions and understandings of entrepreneurship abound.

For entrepreneurship studies to prosper, it is important to develop a clear understanding of the subject under study. Some scholars have defined entrepreneurs by their skills. For instance, political scientist Robert Dahl (1961) and sociologist Neil Fligstein (2001; see also Fligstein and McAdam, 2008) have argued that the key to understanding the effect of 
entrepreneurship lies here. According to Dahl, '[s]kill in politics is the ability to gain more influence than others, using the same resources' (p. 307). Similarly, Fligstein (2001a:107) sees entrepreneurs as societal actors who will be 'more skilful in getting others to cooperate, manoeuvring around more powerful actors, and generally knowing how to build coalitions in political life' [emphasis added]. Fligstein considers creativity to be a key skill, because it enables entrepreneurs to exploit 'cracks' in the societal architecture and find new pathways for exerting influence. Moreover, Mintrom and Norman (2009:852) hold that entrepreneurs need to 'display high levels of social acuity, or perceptiveness' in order to exploit those situations where they are more likely to succeed.

The assumption that skills are the central feature that sets entrepreneurs apart is intuitively appealing. After all, some actors are better at assessing the political context than others and are better at influencing policy development. Sometimes their influence may extend far beyond what could be expected from their formal position or role. In this sense, entrepreneurs do punch above their weight. But: how can we identify such superior abilities and personal attributes in practice? How to operationalize an individual's intrinsic skills and qualities - energy, creativity, or social acuity - in a way that enables us to rank different persons? Moreover, it must be borne in mind that skills may not translate into actions in all situations and at all times.

We find it more fruitful to focus on entrepreneurial strategies and actual actions. In line with this approach, Robert Ackrill and Adrian Kay (2011:78) suggest that entrepreneurship should be regarded 'as a general label for a set of behaviours in the policy process, rather than a permanent characteristic of a particular individual or role'. Indeed, Adam Sheingate (2003:198) even argues that, in the study of entrrpeneurship, it is a mistake to focus on the personal qualities of individuals, 'for this [...] limit[s] the utility of the concept to the study of 'great men'. Instead, the position of entrepreneur is a role that becomes available under certain social conditions, as noted by Fligstein and McAdam (2012:181).

However, it is up to the actors involved in the process to choose to seize the moment and exert entrepreneurship, through various kinds of initiatives. Many political actions are nonentrepreneurial in nature - as with political leaders who mobilize the resources available through their formal positions to implement their political programme, lobbyists who promote the tasks they are hired to promote, and civil servants who try to do what is expected of them. What is needed is an operational definition that makes it possible to distinguish between those actors who perform entrepreneurship and those who do not. We distinguish between the 
entrepreneurship studies that highlight structural strategies, and those that explore and examine cultural/institutional strategies to develop a more tangible definition.

\section{Structural strategies: networking, strategic use of decision-making and information}

We begin by defining structural entrepreneurship as acts aimed at enhancing governance influence by altering the distribution of authority and information (see Boasson, 2015:70). Much of the political science literature on entrepreneurship draws heavily on structural entrepreneurship, highlighting actions such as shrewd networking, coalition-building, alliances, bargaining, venue shopping and strategic use of information. All these strategies aim at overcoming the structural barriers to influence: obstacles created by the distribution of formal authority and/or the distribution of factual and scientific information. Sheingate (2003:186) focuses on structural entrepreneurship, arguing that entrepreneurship will be used to 'establish or challenge jurisdictional monopolies' and for 'changing the boundaries of institutional authority'.

These strategies can be deployed by actors who lack formal access to the decisionmaking arenas responsible for dealing with the climate-policy issues of interest to them, or they may lack access to information as to when, how and where the issues are to be dealt with. For instance, non-governmental actors, like environmental groups and business associations, are rarely present when actual climate-policy issues are dealt with; they may not have direct access to important decision-makers, like cabinet ministers; they might not even be informed of when the final decisions in legislative committees or the government are to be made.

Structural entrepreneurship can be viewed as consisting of three distinct components: the creation of networks; the strategic use of decision-making procedures; and the strategic use of information. All three are techniques that can be used to overcome structural challenges.

First, we will regard networking as a term that covers all activities aimed at mobilizing allies and inducing cooperation among others (Hardy and Maguire, 2008; Leca et al., 2006). It involves various ways of join[ing] actors or groups with widely different preferences and help[ing to] reorder those preferences. (...) The trick is to bring enough on board and keep a bandwagon going that will keep others coming' (Fligstein, 2001a:114). 'Networking' goes under many names in the entrepreneurship literature: as networking (Hardy and Maguire, 2008; Leca et al., 2006), building and maintaining a political coalition (Schneider and Teske, 1992: 740), team-building (Mintrom and Norman, 2009), using personal networks (Mackenzie, 2010:376) and mobilizing domestic support for an agreement (Moravcsik, 1999:272). Here, we 
understand 'network' as collaboration of a fairly loose, informal and temporary character, not to be confused with more enduring structural relationships such as public or private organizational structures.

Networking is a tool for diffusing information, ensuring collaboration and motivating others. In order to create large networks, the entrepreneur needs flexibility. Sometimes, entrepreneurs must be willing to adjust their political projects - and perhaps shift their targets - if that is what is needed in order to get a significant number of actors on board (Fligstein and McAdam, 2012). As Mintrom (1997:739) exaplained, through networking, an entrepreneur learns the worldviews 'of various members of the policymaking community', and this will enable the entrepreneur to persuade actors with high levels of legitimacy or authority to join in. Moreover, entrepreneurs can gain access to actual decision-making situations if they include actors with formal authority in their networks (Roberts and King, 1991:163).

Second, many scholars have noted the strategic and smart use of decision-making procedures and venues. John Kingdon ([1984] 2011) launched the idea of policy windows, and stressed the importance of exploiting them. This relates to timing - launching a proposal when it is most likely to be adopted. Entrepreneurs can enhance their influence by ensuring that their 'pet issue' comes up for decision in a situation that can be expected to produce their preferred outcome; they may also seek to prevent 'their' issue from being included in decision situations seen as ill-suited. Kingdon ([1984] 2011) further argues that entrepreneurs will keep shopping around in search of decision possibilities where they can get their policy ideas on the agenda. This will involve selecting a policy venue that has the authority required to adopt a certain rule or policy and is likely to endorse the proposal in question (Mackenzie, 2010:374). Elin Lerum Boasson and Jørgen Wettestad (2014) take these arguments further, showing how entrepreneurs may try to create extraordinary and/or ad-hoc decision-making procedures while the policy window is open (see Buhr 2012 for a slightly similar argument).

Several authors have focused on specific entrepreneurship techniques related to exploiting the decision-making structure. For instance, Zahariadis (2003:15) speaks of salami tactics: slicing up the policy proposal so as to present smaller, less risky steps sequentially, with each step following logically from the previous one. Moravcsik (1999:272) highlights skilled mediation, in which an entrepreneur intervenes in ongoing negotiations 'to propose new options or compromises'. In a rather similar vein, Ackrill and Kay (2011) argue that entrepreneurs can enhance their influence by performing brokering. 
Third, strategic use of information has been discussed at length by economists and political scientists in general, but has attracted less attention among scholars of entrepreneurship. Andrew Moravcsik (1999:272) notes that, if information is distributed asymmetrically and information is scarce, manipulating who gets what information can be a powerful tool. He argues that expert proposals, influenced by high technical and/or juridical understanding, can be particularly important in such situations (Moravcsik 1999:276). Chris Mackenzie (2010:378) highlights the role of strategic manoeuvring, such as providing as little information as possible to one's likely opponents.

However, networking, the strategic use of decision-making procedures, and the strategic use of information are not the only tools in the entrepreneurial toolbox. Actors seeking to punch above their weight may also perform cultural-institutional entrepreneurship.

\section{Cultural-institutional strategies: positive and negative framing}

Cultural-institutional entrepreneurship highlights what actors may do to ensure that their ideas and suggestions appear more attractive. These strategies aim at altering people's perceptions, norms, cognitive frameworks, worldviews or logics so that they will be positive to the ideas coming from the entrepreneur, and negative to existing and competing policy or governance arrangements. With structural entrepreneurship, actors act entrepreneurially because they lack access to decision-making and decision-makers - but that is not the problem with culturalinstitutional entrepreneurship. In this case, decision-makers (in the view of the entrepreneur) systematically interpret information in the 'wrong way', because they see information and interpret events through a certain prism that steers their societal response (see Huitema and Meijerink, 2009). Cultural-institutional entrepreneurship, then, involves acts aimed at shifting the prism that the decision-makers apply.

'Framing' is perhaps the most common form of cultural-institutional entrepreneurship (see Campbell, 2004; Goffmann, 1974; Snow and Benford, 1988). Another term is 'imagemaking' (Baumgartner and Jones [1993] 2009), whereas analysists of public policy tend to use the term 'persuasion' (see Goodin et al. 2006: 5). Martha Finnemore and Kathryn Sikkink (1998) describe persuasion as the 'mission' of the entrepreneur, and Baumgartner and Jones [1993] 2009:29) hold that 'entrepreneurs use argumentation as a formidable political weapon in their efforts to manipulate political debates'. Mackenzie (2010:376) holds that that 'the ability to argue persuasively is a vital skill that every policy entrepreneur must possess'. 
We regard persuasion and framing as the same phenomenon, and will apply the term 'framing' in referring to a range of actions directed at underpinning or undermining certain ways of understanding and interpreting information and events. Actors may employ rhetoric, symbols, and analysis to frame the policy problem in a way that promotes their views and their preferred solution (Timmermans et al., 2013: 97). According to Fligstein and McAdam (2012:50-51), the basic challenge for entrepreneurs "is to frame "stories" that help induce cooperation from people by appealing to their identity, belief, and interests, while at the same time using those same stories to frame action against various opponents'. Clear and simple articulation and framing of ideas are essential for actors seeking to influence processes of change (Campbell, 2004:178). Several scholars have argued that entrepreneurship can be central for articulating, initiating and introducing new policy ideas into legislative processes (see e.g. Campbell, 2004; Finnemore and Sikkink, 1998; Kingdon, 1984; Mackenzie, 2010: 372; Mintrom, 1997; Moravcsik 1999:272; Sheingate, 2003:188).

Skilful entrepreneurs will craft arguments in different ways for different audiences, especially by framing issues so as to overcome possible objections (Bakir, 2009; Newman; 2008:120-21). In order to persuade others, the entrepreneur must be able to take into account the perspectives of other actors, and create meanings and frames that appeal to a large number of actors (Fligstein, 2001a: 106). To strengthen their arguments in domestic debates, entrepreneurs may also invoke international institutional features, such as norms set out in UN resolutions or EU policies (Boasson, 2005; Finnemore and Sikkink, 1998: 893).

Framing can be done in many ways, and serve multiple purposes, but as a basic delineation we will distinguish between positive and negative framing. Framing can be aimed at creating positive, value-laden and emotional understandings of certain ideas, situations, solutions or target groups - or, conversely, at creating negative, value-laden and emotional understandings of certain other ideas, situations, solutions or target groups (Schneider et al., 2014). Positive framing denotes acts directed at presenting certain policy features as good, desirable, legitimate or appropriate. Bernard Leca and colleagues (2006:23; see also Battilana et al., 2009:68) focus on this kind of entrepreneurship when they define institutional entrepreneurship as acts that break with the institutions existing in a certain societal sphere or field. Entrepreneurs may try to show that their preferred solution is compatible with dominant norms and institutional logics (Greenwood et al., 2002; Leca et al., 2006). The meaning of any given policy proposal, and its link to existing institutional frameworks and logics, may not be obvious: it must be actively constructed by its proponents (Finnemore and Sikkink, 1998:908). 
There will always be the question of whose assessment will count in boosting the legitimacy of a proposal, and whose assessment will not (Scott [1995] 2008: 60). In order to succeed, the skilled entrepreneur must align to the institutional beliefs of groups that hold prominent structural positions (Finnemore and Sikkink 1998: 897, 900). Alternatively, entrepreneurs may try to change the norms and preferences of these groups. Legitimacy may be boosted if it can be proven that a given proposal is in line with current policy trends. This resembles following the latest fashions: the actors aim at conformity with dominant trends, but they also want to outshine 'the common masses' (Sahlin and Wedlin 2008: 223). Mintrom and Norman (2009) highlight a special kind of positive framing: leading by example, creating working models of the proposed change. This refers not only to the use of language and rhetoric, but also to actual (small-scale) actions taken by the entrepreneurs.

Negative framing refers to active de-legitimizing of undesired policies and practices. This may entail ridicule and shaming of existing and competing policy proposals - and the actors who defend them (Scott [1995] 2008). In his classic writings on public administration, James Q. Wilson (1980: 370) argued that this may 'put the opponents of the plan publicly on the defensive (by accusing them of deforming babies or killing motorists)'. State leaders are especially vulnerable to such strategies, because they are particularly keen to avoid public disapproval and shaming (Finnemore and Sikkink, 1998: 867). Mintrom and Norman (2009: 652) argue that it may be highly effective to present 'evidence in a way that suggests that a crisis is at hand'. In practice, negative and positive framing can be combined in various ways and to differing extents. For instance, Paul Copeland and Scott James (2014: 3) highlight the 'strategic construction of narratives that mobilize political action around a perceived policy problem in order to legitimize a particular solution'.

Very few actors will develop policy ideas de novo: they tend to be inspired by impulses from other places or sectors, often creatively editing and altering these original impulses (see Campbell, 2004; Czarniawska and Sevón, 1996). The original idea may be changed because only parts of it fit the entrepreneur's own preferences; or the entrepreneur may wish to make it appear more attractive to potential allies and coalition partners (Sahlin and Wedlin, 2008). Entrepreneurs may also engage in theorizing their preferred policy outcome - specifying, clarifying and generalizing it. The more theorized and abstract an idea is, the more general and easily understandable will the aspects attached to it be. Similarly, actual implementation of a policy idea will make it more specified and 'ready to use' (see Røvik, 2007). 


\section{An operational definition of entrepreneurship}

Against this background, we specify two categories of entrepreneurship: (1) acts aimed at enhancing governance influence by altering the distribution of authority and information; (2) acts aimed at altering or diffusing norms and cognitive frameworks, worldviews or institutional logics. This understanding of entrepreneurship should be sufficiently clear to help us distinguish entrepreneurship from other actions. For instance, if privileged actors in powerful positions deploy the regular tools at their disposal and merely do their job, they are not demonstrating entrepreneurship. A cabinet minister who instructs her civil servants to develop a law in line with her party programme and later endorses the proposal is merely using her structural powers to do what she has been appointed to do. People acting in line with the logics of appropriateness cannot be said to be performing entrepreneurship (March and Olsen, 1989). This understanding of entrepreneurship is also broad enough to open up for research on interesting variance across different aspects of entrepreneurial activities.

\section{Important research questions}

It is essential to enhance our understanding of entrepreneurial strategies and entrepreneurial success. By 'entrepreneurial strategy', we refer to the line of actions pursued. This may fall under the category of structural or cultural-institutional entrepreneurship - or be a combination - but strategies may also vary with respect to target audiences, timing, the number and type of actors involved, the relationship to international political developments, and a range of other factors. Entrepreneurial success concerns actual influence on policy and governance. True, it is challenging to measure influence, but that should not keep us from trying. The operational definition of entrepreneurship presented here underpins research that can distinguish between entrepreneurship and other factors influencing policy and governance. This makes it a good starting point for empirical studies of entrepreneurial success.

The entrepreneurship literature has tended to focus on analysis of 'success cases'. Some authors even state that they regard only those actors that have actually succeeded as 'entrepreneurs'. For instance, Caner Bakir (2009: 572) defines a 'policy and institutional entrepreneur' as 'an individual who mobilizes ideas, resolves conflicts, and steers their implementation for policy and institutional changes' - implying that entrepreneurs will not only try to steer, but will achieve their goals. Similarly, Mark Schneider and Paul Teske (1992: 737) hold that entrepreneurs are 'individuals who change the direction and flow of politics'. 
We feel that political scientist and policy scholars have something to learn from neoinstitutional sociologists (like Fligstein, 2001a; Lawrence et al., 2009; Leca et al., 2006) who recognize that unsuccessful actors may be regarded as entrepreneurs - only that their strategies did not work out in a specific context. Understanding why entrepreneurs are more successful in some cases than in others requires study of unsuccessful cases as well. Sometimes actors encounter very little resistance in their efforts to influence governance and policy. But if that is where the analytical focus is placed, we are studying only instances of success, and risk getting a sample of predominantly 'easy cases'. Only by juxtaposing cases with different outcomes can we gain a better understanding of how contextual factors may impede or enable entrepreneurs to influence policy and governance. Given the importance of mitigating and adopting to climate change, such knowledge is crucial today.

Few researchers have tried to determine the importance of entrepreneurship as contrasted with other explanations of policy change. Attribution issues plague such efforts, but it is clear that entrepreneurship alone cannot explain developments in policy and governance. Studies of policy entrepreneurship need to pay attention to contextual factors, to individual actions within those contexts, and to how context shapes such actions (Mintrom and Norman, 2009:651). Sheingate (2003: 185) suggests that attention should be paid to how 'structural characteristics of institutions might facilitate or frustrate entrepreneurial efforts'; Mackenzie (2010: 379) notes that 'analysis of how, why, and to what degree they [institutions] affect the actions of the policy entrepreneur usually lacks depth.' Varying degrees of success might also be explained partly by differences in the entrepreneurial strategies applied.

Entrepreneurship as 'a context-specific activity'- implying that context influences the strategy, that the strategy in turn influences the ability to succeed, and that some contexts will be more conducive to entrepreneurial success more than others (see Ackrill and Kay, 2011:72, 76). In the following, we discuss how various factors may influence entrepreneurial strategies and entrepreneurial success. Concerning the actors, we are interested in 1) variance in whether the entrepreneurship is directed at securing change or resisting change, and 2) differences in the motivations of entrepreneurs. Other factors relating to the skills of the entrepreneur have been discussed in the literature, but since many of these are hard to measure we do not include them in this discussion. With respect to context, we are interested in 1) public and private governance rules or regimes, 2) policy-window situations, 3) the complexity of the decision-making structure, 4) relationships to international trends 5) whether entrenched cultural-institutional traditions are challenged, and 6) whether powerful segments in society are challenged. 


\section{Actor-specific variation}

Contributions to the entrepreneurship literature have generally focused on entrepreneurship as a vehicle for change (the entrepreneur as a disruptive agent). Mackenzie (2010: 369), for instance, argues that entrepreneurs are 'crucial agents of change in the policy process'. Jos Timmermans and colleagues (2013: 97) regard 'policy entrepreneurs as a source of policy innovations, societal transitions and radical change'. Similarly, Mintrom and Norman (2009: 650) hold that policy entrepreneurs 'distinguish themselves through their desire to significantly change current ways of doing things in their area of interest'. Some authors claim that when policy or governance changes are identified, that means that entrepreneurship must have been involved. For instance, Ann Corbett (2005:152) holds that entrepreneurship is always a necessary condition for policy change. Nancy Roberts (1992) argues that if change can be identified: you can conclude that entrepreneurship has happened, even though you are not able to identify the actors that did it. We do not agree with this approach, noting that many factors other than entrepreneurship may cause policy change: these include exogenous shocks (e.g. financial crisis) as well as slow-moving, gradual path-dependent change (see Pierson, 2004; Streeck and Thelen, 2005). This means that entrepreneurship is neither a necessary nor a sufficient condition for change. Hence, we agree with a central contributor to the entrepreneurship literature, Michael Mintrom, who together with Phillipa Norman (2009:650), points out: 'we should not assume that policy change is always and everywhere driven by policy entrepreneurship'. Entrepreneurship is but one among several possible sources of change.

Moreover, we should remain open to the possibility that an entrepreneur may also be actively involved in blocking such change - a point not often made in the literature. We agree with Ackrill and Kay (2011:78): under certain circumstances, policy entrepreneurs 'may seek defence of the status quo'. In some instances, actors wanting to defend the status quo will have to engage strongly in order to prevent change. In other cases, structural and cultural conditions like organizational structures and dominant cultural-institutional features may protect existing practices so firmly that 'status quo entrepreneurship' is not that warranted (see Boasson, 2015). We believe that entrepreneurship can play a particularly important role in the processes of change relating to mitigating/ adapting to climate change, but we realize that climate actors may also need to defend status quo in some instances - for instance in defence of climate regulations and practices previously introduced, such as $\mathrm{CO}_{2}$ taxation and state aid to renewable energy. 
Variance in whether an actor aims to promote or hinder change is pertinent, as it may influence what entrepreneurial strategies are applied, and also the actor's chances of success. Reflecting the conditions in the entrepreneurship literature, all contributions to this special issue explore actors seeking change. On the other hand, comparative studies of actors that promote change and those that defend the status quo could enable us to identify differences and similarities in the strategies and success of the two types of entrepreneurship.

We now turn to some differences in long-term and short-term political motivations and commitments. There is a clear tendency in the literature to regard only long-term motivations and commitments as relevant for entrepreneurship, but such a starting point may entail undesirable biases. Kingdon employed the striking image of 'surfers waiting for the big wave' ([1984] 2011: 165, see also p. 181); subsequently, many authors have, implicitly or explicitly, assumed that entrepreneurs are actors with a long-term commitment to a certain issue, patiently waiting for the right time to promote it. In line with this, Ugur and Yanjaya (2008:581) argue that only actors 'with a long time horizon' can be regarded as entrepreneurs. Further, Corbett (2005:181) has stressed that all entrepreneurs are 'driven by an idea that they wanted to see enacted'.

Other studies of entrepreneurship, however, have shown that this is not always the case (see Boasson, 2015; Boasson and Wettestad, 2013; Fligstein, 2001; Roberts, 1992). Boasson and Wettestad (2014) hold that variance in the time-horizon of entrepreneurs can be used to distinguish between two different kinds of entrepreneurship: 'tortoises', with long-term commitment to an issue; and 'carpe diem' entrepreneurs, seeking to exploit the opportunity to show their ability to perform political influence. Entrepreneurs may be motivated not so much by stable objectives, as by the urge to prove themselves politically skilled and effective (see Boasson and Wettestad, 2013). Recognizing that entrepreneurs may act on the basis of varying kinds of motivations can pave the way for more empirical studies of whether and how motivation matters for the end result of entrepreneurship. Note, however, that this research agenda requires detailed information about the motivations of the entrepreneurs. It can be difficult to obtain such information, but in-depth interviews with actors who themselves have performed entrepreneurship can provide a valuable source.

In this special issue, Katja Biedenkopf argues that governors in the USA have varied greatly in their motivations for promoting regional ETS, such as ideational, career advancement and juridical interests (understood as support and furthering of state preferences and interests). However, only ideational motivation will lead to stable and continuous entrepreneurship. 


\section{Contextual variation}

Turning to the contextual factors that may contribute to variance in entrepreneurial strategies and success, we begin with the locus of governance: it is private or public? Much of the literature deals, implicitly or explicitly, with the policies of nation-states (still a very important form of governance in the climate domain) - but other modes of governance (like the private sector, civil society) are becoming increasingly significant. The contributors to this special issue adopt a broad understanding of governance entrepreneurship, taking into account all forms of governance - public, private and civil society.

There has been a recent upsurge in private governance initiatives, ranging from carbon reporting to commitments aimed at reducing emissions (Green, 2014; Maor, in this issue; Mintrom and Luetjens, in this issue; Pattberg 2012; Pattberg, in this issue). Jessica Green (2014) identifies entrepreneurship in relation to the development of private authority, or private governance initiatives: with respect to climate change and other environmental issues, firms and non-governmental bodies have managed to develop private authoritative structures at the international level, with undeniable consequences for private and public governance.

By adopting a broader, governance-wide perspective, we can explore whether entrepreneurship plays differing roles in private and public spheres and how of governance in the two spheres may influence each other. Moreover, not much is known about possible differences and similarities in how entrepreneurship unfolds in the two spheres. Three of the contributions to this special issue explore private governance (Mintrom and Luetjens, Maor, and Pattberg) and three explore public governance (Biedenkopf, Jodoin, and Reimer and Saerback). This indicates climate entrepreneurship in both spheres, but as the authors explore widely differing aspects of entrepreneurship, a more structured comparison of differences across the two spheres cannot be developed on the basis of these contributions.

Let us now turn to policy windows, a central context issue in entrepreneurship studies to date. Kingdon [1984] 2011:165) regarded a policy window as 'an opportunity for advocates of proposals to push their pet solutions, or to push attention to their special problems', noting that 'a window opens because of change in the political stream (e.g. change in the administration, a shift in the partsan or ideological distribution of seatrs in Congress, or a shift in national mood): or it opens because a new problem captures the attention (...)'. Many subsequent studies have shown that policy windows enhance entrepreneurial activites and sometimes also entrepreneurial success (see Bakir, 2009; Boasson and Wettestad, 2013; 2014; Buhr, 2012; 
Corbett, 2005; Hermansen, 2015; Ugur and Yanjaya, 2008; Zito, 2011). However, not all actors may realize that a window has opened - and even if they do, they may not always have the time or energy to exploit it (see Boasson, 2015). We can distinguish analytically among various kinds of policy windows - for instance, between problem windows and political windows (Huitema and Sander, 2009).

In this special issue, Biedenkopf discusses how the absence of federal climate policy and the initiation of federal climate policy may create two different policy windows for gubernatorial entrepreneurs; whether these are exploited will depend on the motivations of the potential entrepreneurs, but several contextual factors are also involved. Moreover, Jodoin shows that very different pathways of international influence (international rules, norms, markets and direct access) may help to shape domestic policy windows that can be exploited by entrepreneurs. These two contributions expand our understanding of how the multi-level nature of climate governance contributes to create policy windows - and that this is conducive to entrepreneurship. In order to enhance our understanding of policy windows further we need systematic comparison of differences in entrepreneurial strategies and success across openwindow situations and other situations.

Several studies have shown that complexity in decision-making procedures can create entrepreneurial opportunities and improve the chances of success. Moravcsik (1999: 272) noted that the more complex the issue and the bargaining situation, the more likely is information asymmetry to ensue, thereby creating room for entrepreneurship. Duplication of authority structures, as in the EU, offers greater possibilities for societal groups to exert entrepreneurship (Newman, 2008:121). Mackenzie (2010: 383) observes that the multiplicity of policy forums in Australia's federal political system provides 'policy entrepreneurs with more avenues through which to pursue their innovations'. And Sheingate $(2003: 187,191)$ notes that the heterogeneity of complex systems creates uncertainties that can be exploited by entrepreneurs.

Hence, the literature indicates that complexity leads to both more entrepreneurship and more successful entrepreneurship - but that may be a result of the 'success bias' in the literature. Contributions to this special EPC issue are not exempted here: they all concern decision-making in complex structures, involving entrepreneur actors that have been fairly successful. This makes it even more important to examine cases of unsuccessful entrepreneurship, also in simple decision-making settings.

Several studies show that international impulses can spur entrepreneurship: the involvement of international organizations, politics or policy can create opportunities for 
entrepreneurship (Bakir, 2009; Boasson, 2015; Fligstein and McAdam, 2012:28; Hermansen, 2015). For instance, Boasson (2015) finds that various EU climate policies left significant room for national interpretation, and entrepreneurs exploited the opportunity to perform persuasion and creative bargaining moves. Moreover, actors able to mediate ideas, discourses or other signals of change within and between domestic and international policy communities appear to have better chances of succeeding (Bakir, 2009; Boasson, 2014; Jodoin, this issue; Sheingate, 2003: 194). Hence, it seems that international trends can influence both the entrepreneurial strategies that are applied, and the chances of entrepreneurial success - but more systematic research is needed, comparing issues promoted by international trends with issues primarily rooted in local and national settings.

In this special issue, Jodoin argues that domestic policy entrepreneurs can play a crucial role in activating and harnessing transnational processes of climate governance. International developments can help actors to exploit policy windows, reframe policy solutions and/or problems, building policy coalitions and finding or creating favourable policy venues. A next step in this line of research would be to conduct systematic comparisons of cases that are heavily influenced by international developments with more 'closed' national cases.

Some studies highlight how the absence of strong cultural-institutional traditions (often called 'regulative traditions') may underpin entrepreneurial success - the rationale being that it is easier to paint on a white canvas than on one that already displays a painting. A clear example is the development of the EU Emissions Trading System: the concept was launched at a time where few EU member-states had any other way of regulating carbon emissions, so the idea did not challenge existing traditions (see Boasson and Wettestad, 2014). Green (2014:16) shows that when nation-states fail to agree on how to handle certain environmental issues, this may create a vacuum that allows non-state actors to launch their own governance measures - which, if successful, can then be adopted by states. This finding is in line with the neo-institutionalist analysis of entrepreneurship in sociology, which has indicated that entrepreneurship will be most significant in weakly institutionalized settings (see Battilana et al., 2009: 74; Fligstein, 2001; Fligstein and McAdam, 2012: 51; Hardy and Maguire, 2008).

The two studies of carbon accounting by Maor and by Pattberg in this issue give further support to the argument that the absence of strong cultural-institutional traditions in an issue area will make it easier for entrepreneurs to succeed. They both describe how entrepreneurship played key roles in establishing carbon accounting practices. Pattberg notes that, after several templates for carbon accounting had emerged, entrepreneurship was required in order to ensure 
more streamlining of these processes. Biedenkopf (also in this issue) presents a more nuanced picture, showing how the absence of federal carbon pricing has both obstructed and spurred US governors to initiate state-level schemes, depending on their intrinsic motivations.

It seems logical to expect entrepreneurship to have poor chances of succeeding if it challenges powerful segments or sectors in society. However, the literature has not explored this systematically. Boasson (2015) has shown that impressive entrepreneurial efforts from scientists, the environmental movement and politicians led to the adoption of significant volumes of carbon capture and storage (CCS) policy measures in Norway - but this was not sufficient to counteract the structural power of the petroleum sector: despite all entrepreneurial efforts, no full-scale CCS facilities were constructed. The study also indicates that entrepreneurs who challenge powerful segments must perform a whole range of entrepreneurial strategies, structural as well as cultural-institutional in character. Boasson (2015) compares this with cases where the targeted segment was less powerful - and finds that policy areas where entrepreneurial success is highly unlikely may foster more entrepreneurial activities than issue areas where it appears likely. A paradox: as it takes more to succeed when resistance is strong, entrepreneurs may be more active in areas where they are the least likely to succeed.

Few contributions to this special issue explicitly explore entrepreneurship that challenge powerful sectors in the society. The exception is Biedenkopf, who argues that lack of federal carbon pricing, combined with economically powerful actors who have much to lose from pricing, creates a context where potential entrepreneurs may gain much (in terms of political reputation) but at high risk (of not succeeding). Her article supports the argument that entrepreneurship will seldom be successful when opposed by powerful segments of society, whereas her point that potential political gains are especially high in these situations helps to explain why some politicians still rise to the occasion. How entrepreneurship fares when challenged by powerful societal segments is indeed a topic that warrants more research, both with respect to variance of entrepreneurial strategies and entrepreneurial success.

\section{Conclusions}

Entrepreneurship approaches to climate policy and governance studies are important for many reasons, perhaps most significantly because they allow us to capture causal explanations that are overlooked by other approaches - and not because they can explain everything (Sheingate, 2003). In this introduction, we have specified two types of entrepreneurship: acts aimed at enhancing governance influence by altering the distribution of authority and information; and acts aimed at altering or diffusing norms and cognitive frameworks, worldviews or institutional 
logics. Against this backdrop, we have assessed the state of the art within the literature and identified a set of crucial research questions. There exists an extensive literature on entrepreneurship, but much remains to be done to develop a research tradition that can foster cumulative research.

Table 1 summarizes key questions for future research and how this special issue contributes to this research agenda. Today, it is essential to enhance our knowledge about the factors that conditions variance in entrepreneurial strategies as well as success. Admittedly, it is very demanding to disentangle the relative importance of entrepreneurship from other factors that drive policy and governance. However, that does not mean that we should not try to develop a better understanding of the relative importance of entrepreneurship.

As shown in Table 1, this special issue contributes new perspectives and findings on personal motivations, policy windows, international trends, cultural-institutional traditions and structural power distribution. As regards the promotion of change or the status quo, and public versus private governance, the entrepreneurship studies in this issue display similar tendencies as seen in the entrepreneurship literature otherwise. Further exploration of these issues is likely to require more coherent, collaborative and systematic comparative research, beyond what a single special issue of this journal may provide. As highlighted by Green in her conceptual discussion paper in this issue, it is essential to encourage more comparative research in order to enhance the research agenda on climate governance. While Green presents a range of specific hypotheses to be explored in comparative research projects, Table 1 identifies key comparative research questions. It is our hope that this special issue will inspire researchers to set about finding firmly grounded answers to these questions. 
Table 1. Research questions for climate entrepreneurship research agenda

\begin{tabular}{|c|c|c|c|c|}
\hline & $\begin{array}{l}\text { Elements of } \\
\text { variation }\end{array}$ & $\begin{array}{l}\text { Entrepreneurial } \\
\text { strategies } \\
\text { To what extent and how } \\
\text { will entrepreneurial } \\
\text { strategy vary between.... }\end{array}$ & $\begin{array}{l}\text { Entrepreneurial } \\
\text { success } \\
\text { To what extent will } \\
\text { entrepreneurial success } \\
\text { vary between actors .... }\end{array}$ & $\begin{array}{l}\text { Contributions in this } \\
\text { special issue of EPC }\end{array}$ \\
\hline \multirow[t]{2}{*}{ Actor } & $\begin{array}{l}\text { Promotion of change } \\
\text { or status quo }\end{array}$ & $\begin{array}{l}\text {...change-promoters, and } \\
\text { defenders of the status } \\
\text { quo? }\end{array}$ & $\begin{array}{l}\text {...that promote change, } \\
\text { and actors seeking to } \\
\text { secure the status quo? }\end{array}$ & $\begin{array}{l}\text { All contributions explore } \\
\text { promotion of change. }\end{array}$ \\
\hline & Personal motivations & $\begin{array}{l}\text {...actors with long- and } \\
\text { short-term commitments? }\end{array}$ & $\begin{array}{l}\text {...with long-term rather } \\
\text { than short-term } \\
\text { commitments? }\end{array}$ & $\begin{array}{l}\text { Biedenkopf explores what } \\
\text { may create long-term } \\
\text { commitments }\end{array}$ \\
\hline \multirow[t]{6}{*}{ Context } & $\begin{array}{l}\text { Public or private } \\
\text { governance }\end{array}$ & $\begin{array}{l}\text {...public and private } \\
\text { governance? }\end{array}$ & $\begin{array}{l}\text {...that target public } \\
\text { governance, and actors } \\
\text { that target private } \\
\text { governance? }\end{array}$ & $\begin{array}{l}\text { None explicitly compare. } \\
\text { Pattberg, Maor, Mintrom } \\
\text { and Luetjens assess } \\
\text { private governance. }\end{array}$ \\
\hline & Policy window & $\begin{array}{l}\text {...situations with an open } \\
\text { window, and situations } \\
\text { without an open window? }\end{array}$ & $\begin{array}{l}\text {...that operate in a policy } \\
\text { window, and actors that } \\
\text { do not? }\end{array}$ & $\begin{array}{l}\text { Biedenkopf explores } \\
\text { windows created by } \\
\text { federal policy (or lack } \\
\text { thereof). }\end{array}$ \\
\hline & $\begin{array}{l}\text { Complexity of } \\
\text { decision-making } \\
\text { structure }\end{array}$ & $\begin{array}{l}\text {...complex and simple } \\
\text { decision-making } \\
\text { structures? }\end{array}$ & $\begin{array}{l}\text {...that operate in } \\
\text { complex rather than } \\
\text { simple decision-making } \\
\text { structures? }\end{array}$ & $\begin{array}{l}\text { All cases indicate that } \\
\text { climate government. } \\
\text { entrepreneurship tends to } \\
\text { occur in complex } \\
\text { settings. }\end{array}$ \\
\hline & $\begin{array}{l}\text { International } \\
\text { impulses }\end{array}$ & $\begin{array}{l}\text {...issues that are part of } \\
\text { larger international trends, } \\
\text { and issues that emerge in } \\
\text { isolation? }\end{array}$ & $\begin{array}{l}\text {..that gain support from } \\
\text { international trends, and } \\
\text { actors that do not? }\end{array}$ & $\begin{array}{l}\text { Jodoin conceptualizes } \\
\text { the relationship between } \\
\text { national impulses and } \\
\text { entrepreneurial } \\
\text { strategies. }\end{array}$ \\
\hline & $\begin{array}{l}\text { Cultural-institutional } \\
\text { traditions }\end{array}$ & $\begin{array}{l}\text {...issues that fit cultural- } \\
\text { institutional traditions, and } \\
\text { issues that challenge } \\
\text { these? }\end{array}$ & $\begin{array}{l}\text {...that aligned with } \\
\text { cultural-institutional } \\
\text { trends, and actors that } \\
\text { challenge these? }\end{array}$ & $\begin{array}{l}\text { Pattberg and Jodoin } \\
\text { indicate that lack of } \\
\text { traditions is conducive, } \\
\text { Biedenkopf offers mixed } \\
\text { conclusions }\end{array}$ \\
\hline & $\begin{array}{l}\text { Structural power } \\
\text { distribution }\end{array}$ & $\begin{array}{l}\text {...issues that fit the } \\
\text { preferences of structurally } \\
\text { powerful actors, and } \\
\text { issues that challenge } \\
\text { these? }\end{array}$ & $\begin{array}{l}\text {...actors that that } \\
\text { promote the preferences } \\
\text { of structurally powerful } \\
\text { actors, and actors that } \\
\text { challenge these actors? }\end{array}$ & $\begin{array}{l}\text { Biedenkopf argues that } \\
\text { structural misfit produces } \\
\text { high gain at high risk for } \\
\text { potential entrepreneurs. }\end{array}$ \\
\hline
\end{tabular}

\section{References}

Abbott KW (2015) Orchestration. In: Pattberg P and Zelli F (eds) Encyclopedia of Global Environmental Governance and Politics. Cheltenham: Edward Elgar.

Ackrill R and Kay A (2011) Multiple streams in EU policy-making: the case of the 2005 sugar reform. Journal of European Public Policy 18 (1):72-89.

Ackrill R, Kay A and Zahariadis N (2013) Ambiguity, multiple streams, and EU policy. Journal of European Public Policy 20 (6): 871-887. 
Bakir C (2009) Policy entrepreneurship and institutional change: multilevel governance of central banking reform. Governance: An International Journal of Policy, Administration, and Institutions 22(4): 571-598.

Battilana J, Leca B and Boxenbaum E (2009) How actors change institutions: towards a theory of institutional entrepreneurship. Academy of Management Annals 3(1): 65-107.

Baumgartner FR and Jones BD ([1993] 2009) Agendas and Instability in American Politics. 2nd edn. Chicago, IL: University of Chicago Press.

Bernier, L and Hafsi T (2007) The changing nature of public entrepreneurship. Public Administration Review, 67 (3): 488-503.

Biedenkopf K (2017, this issue) Gubernatorial entrepreneurship and United States federal-state interaction: The case of subnational regional greenhouse gas emissions trading. Environment and Planning C: Politics and Space.

Boasson EL (2015) National Climate Policy: A Multi-Field Approach. London: Routledge.

Boasson EL and Wettestad J (2013) EU Climate Policy: Industry, Policy Interaction and External Environment. Aldershot: Ashgate.

Boasson, EL and Wettestad J (2014) Policy innovation and entrepreneurship: bankrolling the burying of carbon in the EU Global Environmental Change. Global Environmental Change 29 (special issue on Climate Policy Innovation): 404-412.

Brouwer S (2013) Policy Entrepreneurs and Strategies for Change: The Case of Water Management in the Netherlands. PhD thesis, VU University Amsterdam,.

Buhr K (2012) The inclusion of aviation in the EU Emissions Trading Scheme: temporal conditions for institutional entrepreneurship. Organization Studies (33): 1565-1587.

Bulkeley H, Andonova L, Bäckstrand K, Betsill M, Compagnon D, Duffy R, Kolk A, Hoffmann M, Levy D, Newell P, Milledge T, Paterson M and Pattsberg P (2012), Governing climate change transnationally: assessing the evidence from a survey of sixty initiatives. Environment and Planning C: Government and Policy 30: 591-612.

Campbell, JL (2004) Institutional Change and Globalization. Princeton, NJ: Princeton University Press.

Copeland P and S James (2014) Policy windows, ambiguity and Commission entrepreneurship: explaining the relaunch of the European Union's economic reform agenda. Journal of European Public Policy 21 (1): 1-19.

Corbett, A (2005) Universities and the Europe of Knowledge: Ideas, Institutions and Policy Entrepreneurship in European Union Higher Education Policy, 1955-2005. New York: Palgrave Macmillan.

Czarniawska B and Sevón G (eds) (1996) Translating Organizational Change. Berlin: de Gruyter.

Dahl, RA (1961) Who Governs? Democracy and Power in an American City. New Haven, CT: Yale University Press. 
Dubash NK, Hagemann M, Höhne N and Upadhyaya P (2013) Developments in national climate change mitigation legislation and strategy. Climate Policy 13 (6): 649-664.

Finnemore M and K Sikkink (1998) International norm dynamics and political change. International Organization 52: 887-917.

Fligstein N (2001) Social skill and the theory of fields. Sociological Theory 19 (2): 105-125.

Fligstein N and McAdam D (2012) A Theory of Fields. Oxford: Oxford University Press.

Goodin RE, Rein M and Moran M (2006) The public and its policies. In: Moran M, Rein M and Goodin RE (eds) Oxford Handbook of Public Policy. Oxford: Oxford University Press, pp. 3 -35.

Green J (2014) Rethinking Private Authority: Agents and Entrepreneurs in Global Environmental Governance. Princeton, NJ: Princeton University Press.

Green J (2017 this issue) Policy entrepreneurship in climate governance: toward a comparative approach. Environment and Planning C: Politics and Space.

Hardy C and Maguire S (2008) Institutional entrepreneurship. In: Greenwood R, Oliver C, Sahlin K and Suddaby R (eds) SAGE Handbook of Organizational Institutionalism. Thousand Oaks, CA: Sage, pp. 198-217.

Hermansen, EAT (2015) Policy window entrepreneurship: the backstage of the world's largest REDD+ initiative. Environmental Politics 24 (6): 932-950.

Huitema D. and S. Meijerink (eds) (2009) Water Policy Entrepreneurs. Cheltenham: Edward Elgar

Huitema D and Meijerink S (2010) Realizing water transitions: the role of policy entrepreneurs in water policy change. Ecology and Society 15 (2) 26, online: http://www. ecologyandsociety.org/vol15/iss2/art26/.

Jodoin S (2017, this issue) The transnational policy process for REDD+ and domestic policy entrepreneurship in developing countries. Environment and Planning C: Politics and Space

Jordan A, Huitema D, Hildén M, van Asselt H., Rayner TJ, Schoenefeld JJ, Tosun J, Forster JA and Boasson EL (2015) Emergence of polycentric climate governance and its future prospects. Nature Climate Change (5):977-982.

Kingdon JW ([1984] 1995) Agendas, Alternatives, and Public Policies. Boston, MA: Little, Brown.

Leca B., Battilana, J and Boxenbaum E (2006) Taking stock of institutional entrepreneurship: What do we do now? Where do we go? Paper presented at the Academy of Management Meetings, 11-16 August, Atlanta, GA.

Lovell H (2009) The role of individuals in policy change: the case of UK low-energy housing. Environment and Planning C: Government and Policy 27: 491-511.

Maor M (2017, this issue) Policy entrepreneurs in policy valuation processes: the case of the Coalition for Environmentally Responsible Economies. Environment and Planning C: Politics and Space. March, JG and Olsen JP (1989) Rediscovering Institutions. New York: Free Press. 
Mackenzie C (2010) Policy entrepreneurship in Australia: a conceptual review of application. Australian Journal of Political Science 39 (2): 367-386.

Mintrom M (1997) Policy entrepreneurs and the diffusion of innovation. American Journal of Political Science, 41(3): 738-770.

Mintrom M and Norman P (2009) Policy entrepreneurship and policy change. Policy Studies Journal 37 (4): 649-667.

Mintrom M and Luetjens J (2017, this issue) Policy entrepreneurs and problem framing: the case of climate change. Environment and Planning C: Politics and Space.

Moravcsik A (1999) A new statecraft? Supranational entrepreneurs and international cooperation. International Organization 53(2): 267-306.

Newman AL (2008) Building transnational civil liberties: transgovernmental entrepreneurs. International Organization 62 (Winter): 103-130.

Pattberg P (2012) How climate change became a business risk: analyzing nonstate agency in global climate politics. Environment and Planning C: Government and Policy 30: 613-626.

Pierson P (2004) Politics in Time: History, Institutions and Social Analysis. Princeton, NJ: Princeton University Press.

Polsby NW (1984) Political Innovation in America: The Politics of Policy Initiation. New Haven, CT: Yale University Press.

Roberts N (1992) Policy entrepreneurship and innovation. Policy Studies Review 11: 55-74.

Roberts N and King PJ (1991) Policy entrepreneurs: their activity structure and function in the policy process. Journal of Public Administration Research and Theory 1(2): 147-175.

Røvik, KA (2007) Trender og translasjoner: ideer som former det 21. århundrets arbeidsliv. Oslo: Universitetsforlaget.

Sahlin K and Wedlin L (2008) Circulating ideas: imitating, translation and editing. In: Greenwood R, Oliver C, Sahlin K and Suddaby R (eds) SAGE Handbook of Organizational Institutionalism. Thousand Oaks, CA: Sage, pp. 219-242.

Schneider M and P Teske (1992) Toward a theory of the political entrepreneur: evidence from local government. American Political Science Review 86 (3): 737-747.

Schneider, AL, Ingram H and deLeon P (2014) Democratic policy design: social construction of target populations. In: Sabatier, PA and Weible CM (eds) Theories of the Policy Process. Boulder, CO: Westview Press, pp. 183-208.

Scott WR ([1995] 2008) Institutions and Organizations: Ideas and Interests, $3^{\text {rd }}$ edn. Thousand Oaks, CA: Sage.

Sheingate AD (2003) Political entrepreneurship, institutional change, and American political development. Studies in American Political Development 17: 185-203. 
Snow D and R Benford (1988) Ideology, frame resonance, and participant mobilization. In: Klandermans B, Kriesi H and Tarrow S (eds), From Structure to Action: Comparing Social Movement Research Across Cultures (International Social Movement Research, Volume 1). Greenwich, CT: JAI Press, pp. 197-218.

Somanathan E, Sterner T and T Sugiyama (2014) National and sub-national policies and institutions. Intergovernmental Panel on Climate Change Working Group III Mitigation of Climate Change. Cambridge: Cambridge University Press, Chapter 15.

Streeck, W and Thelen K (2005) Beyond Continuity: Institutional Change in Advanced Economies. Oxford: Oxford University Press [Kindle version].

Timmermans JS, van der Heiden S and Born MP (2013) Policy entrepreneurs in sustainability transitions: their personality and leadership profiles assessed, Environmental Innovation and Societal Transitions 13: 96-108.

Ugur M and Yanjaya D (2008) Policy entrepreneurship, policy opportunism and EU conditionality: the AKP and TÜSIAD experience in Turkey. Governance: An International Journal of Policy, Administration and Institutions 21 (4):581-601.

Underdal A (2002) One question, two answers. In: Miles EL, Underdal A, Andresen S, Wettestad J, Skjærseth JB, and EM Carlin (eds) Environmental Regime Effectiveness. Cambridge, MA: MIT Press, pp. 3-45.

Wejs A (2014) Integrating climate change into governance at the municipal scale: an institutional perspective on practices in Denmark. Environment and Planning C: Government and Policy 32: 1017-1035.

Wettestad J (2003) The making of the 2003 EU Emissions Trading Directive: an ultra-quick process due to entrepreneurial proficiency? Global Environmental Politics 5 (1): 1-23.

Wilson, JQ (1980) The Politics of Regulation. New York, NY: Basic Books.

Zahariadis N (2003) Ambiguity and Choice in Public Policy: Political Manipulation in Democratic Societies, Washington, DC: Georgetown University Press.

Zito A (2011) Epistemic communities, collective entrepreneurship and European integration. Journal of European Public Policy 8(4): 585-603. 